Article

\title{
Emancipating Intellectual Property from Proprietarianism: Drahos, Foucault, and a Quasi-Genealogy of IP
}

\author{
Wendyl Luna \\ School of Humanities and Languages, University of New South Wales, Sydney, NSW 2052, Australia; \\ wendyl.luna@student.unsw.edu.au
}

Received: 15 November 2017; Accepted: 15 January 2018; Published: 18 January 2018

\begin{abstract}
This paper argues that Peter Drahos undertakes a partial Foucauldian genealogy by emancipating intellectual property (IP) from proprietarianism. He demonstrates the dominance of proprietarianism in IP by drawing sample practices from trademark, copyright, and patent laws, and then seeks to displace the proprietarian dominance with instrumentalism, which reconstitutes IP as a "liberty-intruding privilege." Ironically, despite doing a genealogy, Drahos does not eradicate sovereignty altogether as Michel Foucault insists, but instead determines IP as a "sovereignty mechanism" that has a "sovereignty effect." After explaining what Foucauldian genealogy is, the paper will explain how Drahos undertakes a genealogy of IP, while highlighting the limitations of Drahos' analysis from a Foucauldian perspective.
\end{abstract}

Keywords: Michel Foucault; Peter Drahos; (quasi-)genealogy; intellectual property/IP

\section{Introduction}

Although he explicitly references two of Michel Foucault's works and briefly examines his notion of power, it would misrepresent Peter Drahos to say he was inspired by Foucault for his genealogical work of IP. Nevertheless, the minimal Foucauldian inspiration does not prevent it from being said that Drahos undertakes a genealogy. By resisting the common temptation to understand IP as "property" or to view it from a proprietarian perspective, as well as by considering it instead as a "liberty-intruding privilege," Drahos allows us to rethink the notion of intellectual property from an instrumental point of view.

This paper has a twofold aim: first, to show that Foucault's genealogy provides a useful and still relevant approach to analyzing rights and power relations, especially in the specific context of IP; and, second, to explore the difficulties of strictly following genealogical principles in the context of intangible (statutory) rights, such as IP in that they require an acknowledgement of sovereignty as a foundational basis for affirming precisely those rights. Its importance then lies not only in examining Drahos' work from a Foucauldian perspective, but also in pointing out potential responses to the high demands of strictly applying Foucauldian genealogy. Examining Drahos' quasi-genealogy of IP in his book, A Philosophy of Intellectual Property (Drahos 2016), this paper demonstrates that, despite falling short of Foucauldian genealogy, Drahos confirms the usefulness of such a genealogy as one of the tools in analyzing regimes beyond those which were the specific subject of study by Foucault (e.g., sexuality or disciplinary society).

I will first briefly outline how Foucault conceives of genealogy, and then examine Drahos' emancipation of IP from the shackles of proprietarianism via instrumentalism as a genealogical undertaking. In lieu of a property rights characterization, Drahos suggests applying the "language of privilege" which, he says, "should form the core of intellectual property theory" (Drahos 2016, p. 2). With this, Drahos validates Foucault's genealogical approach by applying its core principles, although 
not fully, because he refuses to sever ties with sovereignty as Foucault would demand (Drahos 2016, p. 176). The question to ask Drahos, then, is whether it would be possible to truly liberate IP from proprietarianism if one still clings on to sovereign power in some form.

The paper is divided into three parts: (1) Foucauldian genealogy: otherwise than government;

(2) Proprietarianism: the norm in IP; and (3) Drahos' departure from Foucault: a quasi-genealogy. The first part will discuss Foucauldian genealogy through a reading of Foucault's "What is Critique?" to show that it is primarily an immanent critique of the present. Next, I will examine Drahos' genealogy of IP, which consists of determining proprietarianism as the dominant norm in IP, as well as displacing it with instrumentalism. The final section will explain why Drahos' genealogy of IP is a quasi-genealogy. Even though his genealogy may well be considered Foucauldian, he undertakes Foucauldian genealogy only partially. For, despite displacing successfully the dominant proprietarian view in IP with an instrumental one, he, unlike Foucault, refuses to "cut off the head of the king."

\section{Foucauldian Genealogy: Otherwise Than Government}

Much has already been said about Foucauldian genealogy, and it is useful to explore what others have said to provide context before engaging directly with Foucault himself. While stressing that Foucault's genealogy is closely linked to his questioning of the present, Colin Gordon argues that in order to specify the singularity of Foucault's genealogical work, it must be compared with other genealogical works of Cassirer, Hayek, Adorno, and other genealogists (Gordon 1986, p. 78). Likewise, the title of Rudi Visker's book, Michel Foucault: Genealogy as Critique, already gives us a hint as to how he understands Foucault's genealogy. Its utilization of quotation marks, he says, is "an exemplary expression of a model of critique" (Visker 1995, p. 2). Furthermore, he argues that Foucault's use of quotation marks, which he says should neither be exaggerated nor taken seriously (Visker 1995, p. 2), structures his critique of subjectivity, power, and the pretentious claims to scientificity of the so-called "sciences" such as psychoanalysis and the human sciences (Visker 1995, p. 110). Like Visker, Colin Koopman gives his book the same title, whose "central aim," he says, is to explain that genealogy is a "philosophical-historical critique of the present" (Koopman 2013, p. 5). ${ }^{1}$ While acknowledging his indebtedness to Foucault, he nonetheless seeks to revise Foucault, as well as reconstruct his "problematization" of modernity. Joseph Tanke is another Foucauldian scholar who deals with Foucault's genealogy of modernity. Scrutinizing Foucault's philosophy of (visual) art that deals with the paintings of such artists as Velázquez, Manet, and Magritte, he claims that this Foucauldian corpus forms a different "strand in the historical ontology of ourselves," constituting a significant part of Foucault's critique of modernity (Tanke 2009, pp. 4-6).

Finally, Foucault and the History of Our Present (Fuggle et al. 2015) is a rich collection of essays, which explain Foucault's "history of the present", not by reiterating what he said, but by identifying those interstices out of which new forms of subjectivities and struggles may be illumined. In her essay, for example, Judith Revel explains that the "modern attitude" Foucault elaborates in "What is Enlightenment?" comprises two attitudes ((a) critical-historical; and (b) experimental), which together make his genealogy an immanent critique of the present. ${ }^{2}$ This brief, non-exhaustive survey shows that, in spite of the many interpretations of Foucauldian genealogy, a common theme emerges: genealogy is a form of critique. To elaborate such a critique and to add something to this already rich literature on Foucauldian genealogy, I propose to examine Foucault's "What is Critique?" Considering this text should not only give a clearer idea about what Foucault means by critique and/or genealogy but should also illuminate why Drahos' genealogy of IP may be described as Foucauldian, albeit partially.

1 Critical reviews of Koopman's book, to which he replies (Koopman 2014), appear in appear in 2014. Foucault Studies 18 : 238-60. See (Allen 2014; Mendieta 2014; Olson 2014).

2 Revel writes: "We never exit from history, but we always experiment inside it. That is, we invent from the very inside of a present state of historical determinations of an already-there of history" (Revel 2015, p. 23). 
In the lecture addressed to the French Society of Philosophy on 27 May 1978, which would become known widely as "What is Critique?", Foucault gives his threefold definition of "critique": general, historical, and analogical; in this section, I will focus on Foucault's historical definition of critique. Generally speaking, critique is captured by what he calls the "critical attitude," which he defines as a mode of "thinking, speaking and acting" (Foucault 2007a, p. 42). Likewise, in general terms, critique or critical attitude is a type of relationship one has with things, other people, and one's self. Foucault argues that critique is essentially different from, or in stark contrast to, government or the art of governing others. As such, critique may be said to be otherwise than government.

Peculiar to the West, Foucault traces the roots of the art of governing others to the Christian pastoral that advances its own notion of governing others; namely, that everyone needs to be governed or directed by an able person to salvation. In Foucault's account, this art of governing others saw an expansion into spheres beyond religion in the fifteenth century for two reasons. The art of governing spread first because of secularization. This means that such an art is not a question of saving souls anymore, and is no longer done exclusively by the priest, but extends beyond the religious sector to the secular part of society. The second reason for the expansion is that, while it was previously confined to the church, the art of governing others could then be accomplished in different areas, such as governing children, families, cities, and others. Hence, the art of governing which, in Foucault's analysis, Christianity started during the medieval times, multiplied or proliferated in the fifteenth or sixteenth century because the arts of governing and the institutions of government themselves diversified. ${ }^{3}$

What is more interesting than the proliferation of the arts of governing is that any art of governing, according to Foucault, is always accompanied by its counter-movement, which I call the refusal to be governed in a certain way or the refusal to follow an existing form of "power." Moreover, he says that it is with the refusal to be governed in a certain way that one can align or locate the critical attitude. Two movements can then be juxtaposed: on the one hand, the art of governing; and, on the other hand, the refusal to follow this form of governing. Foucault argues that the art of governing and the refusal to be governed in a certain way are two sides of the same coin, and are inseparable; as such, the refusal is always tied to a particular form or art of governing. Whereas the fundamental question of the art of governing is "how to govern," the question of its counter-movement is "how not to be governed like that." ${ }^{4}$ If the two are always tied together, and if the art of governing has multiplied, then it would be safe to say that the refusal to be governed in a certain way has also multiplied, even though Foucault does not explicitly say this in his lecture. Having identified its beginnings, Foucault determines the historicity of critique. From this, one can say that Foucault's historical definition of critique is such that it pins down to a certain period in history the proliferation of the critical attitude or the refusal to be governed in a certain way.

Foucault presents three points that anchor, if not determine, critique historically (Foucault 2007a, pp. 45-47). The first historical point of the critical attitude or refusal to be governed in a certain way is the defiance or opposition against the authority of the Church over the interpretation of scriptures. This refusal to be governed by what the magisterium says about scriptures seeks to go back to the "truth" or real meaning that is embedded in scriptures. This makes critique or the refusal to be governed in a certain way to manifest as exegesis or biblical hermeneutics, which, unlike eisegesis, allows the text to speak for itself as it were, hence a much better way of approaching or interpreting the Bible. The second historical point of this critical attitude is found in the refusal to obey unjust laws. This refusal enables people to come up with fundamental and inalienable rights that all governments

3 After giving the lecture, Foucault says during the panel discussion: "[T]he history of the critical attitude, as it unfolds specifically in the West and in the modern Western world since the 15th-16th centuries must have its origin in the religious struggles and spiritual attitudes prevalent during the second half of the Middle Ages, precisely at the time when the problem was posed: how should one be governed, is one going to accept being governed like that?" (Foucault 2007a, p. 69).

4 Foucault writes: "[T]his governmentalization [i.e., the art of governing or how to govern], which seems to me to be rather characteristic of these societies in Western Europe in the 16th century, cannot be dissociated from the question 'how not to be governed?'" (Foucault 2007a, p. 44). 
must recognize, making critique a legal issue. This second point also indicates that the art of governing has limits and that it has no absolute authority. The final historical point is the refusal to submit to the authority of dogmatism. This refusal opposes a particular authority of dogmatism, and submits to it only if one discovers that it is just and reasonable. Critique, then, is found wherever there is an unreasonable, unjust, and corrupt status quo. The refusals are each connected to a particular form of governing at all times. With Foucault's three examples of different refusals against existing forms of "power," critique is defined historically. It is very interesting to see that the critical attitude can be found even outside the province of philosophy, as if Foucault is saying that it is not exclusively a problem for philosophy.

If one examines Foucault's definition of critique, however, she finds that it is quite narrow, because it is identified only as a refusal to be governed in a certain way. Moreover, one has reason to ask whether Foucault is correct in saying that this critical attitude began as a reaction to the Christian pastoral, and then carried over through the 15th and 16th centuries up to our times. A question can be raised: is there no critical attitude in the East? One can also ask whether there was no critical attitude before the refusal to follow the Christian pastoral. Henri Gouhier, who was one of the interlocutors during the panel discussion, actually wondered whether it is possible to trace Foucault's account of the critical attitude to the Socratic method, saying: "there is a critical ferment due to Socratic thought" (Foucault 2007a, p. 73). What if, to use Foucault's language, these critical attitudes or different refusals are actually dispersed and disconnected? He himself acknowledged at the beginning of his lecture that the critical attitude peculiar to the Western tradition is "condemned to dispersion, dependency and pure heteronomy" (Foucault 2007a, p. 42). Therefore, there are two contrasting Foucauldian ideas of critical attitude: one which is dispersed or heteronomous, and the other which can be historically unified or connected.

It would appear difficult to make sense of the critical attitude as both dispersed and unified. The different critical attitudes occurring at different times in the history of the West only seem to be historically unified or connected because Foucault, the historian-philosopher, tries to connect these dispersed objects. This is perhaps not faithful to the historiography or the approach to history he proposes in The Archaeology of Knowledge (Foucault 2002); namely, that dispersed objects are to be respected as they are, and accounted for precisely as dispersed objects. It is highly unlikely that our current refusals to follow unjust forms of governing today (or at any time) are mere reprisals of the critique or critical attitude of the past (even before the Christian pastoral). Our criticism of Foucault's historicizing the critical attitude, therefore, is this: in contrast to seeing critique as that which can be historically connected, critique is considered not as a continuation of the critical attitude of the past, but one that is done with respect to any unjust, unreasonable, and corrupt status quo or current art of governing.

Whether or not Foucault is right in historicizing the critical attitude, one can still agree with him that many forms of governing are stifling, and there will always be a refusal or critical attitude that is tied up with each of these forms. If the art of governing stifles or subjugates individuals, the refusal to be governed in a certain way de-subjugates and empowers them. It is worth quoting Foucault at length:

[I] governmentalization is indeed this movement through which individuals are subjugated ... I will say that critique is the movement by which the subject gives himself the right to question truth on its effects of power and question power on its discourses of truth ... critique will be the art of voluntary insubordination, that of reflected intractability. Critique would essentially insure the desubjugation of the subject in the context of ... the politics of truth. (Foucault 2007a, p. 47; emphases mine).

The quotation above is a good summary of what I have been trying to say so far: critique or critical attitude is the process by which one de-subjugates or frees oneself from oppressive and stifling forms of governing (i.e., a "voluntary insubordination"). It is to question, or hold as suspect, both "truth" and "power"; namely, "truth" that produces power, and "power" that articulates truth. Not subscribing 
to the correspondence theory of truth, Foucault argues that "truth" is a product of power relations. It is malleable, ephemeral, contingent, and dependent on various forces, such as institutions. If it were to question "truth," then critique questions not only those "truths" that are held to be true, but also those that produce and have an effect on power. On the other hand, there is a kind of "power" that expresses truth and, while doing so, subjugates individuals. This conception of power seems to be different from the notion of power that Foucault talks about in his other works, such as The History of Sexuality, where he conceives of power as that which is constituted, supported, and conditioned by force relations. Power, in this sense, is not something negative, but productive and positive. ${ }^{5}$ It is important to take note of this positive sense of power because, as we will see, Drahos shares the same view. In his lecture, however, the "power" that Foucault has in mind is something negative: it stifles and subjugates individuals.

It might be thought that Foucault is inconsistent here, because he presents a seemingly contradictory notion of power in "What is Critique?" However, if we follow his idea found in The History of Sexuality, that the power that subjugates is merely an effect of the positive "power" that is constituted and conditioned by the various power relations, then the former is not foreign to the latter. There is therefore no contradiction on Foucault's part. He is using the same "grid" of power to analyze the critical attitude. Nevertheless, we have these forms of governing that are "powerful" (those that express and define "truth") and "truthful" (those that produce "power") and, as such, they are stifling and subjugating. In opposition to these stifling, "powerful", and "truthful" forms of governing, the critical attitude relates itself to them, and seeks to free itself from them.

The remainder of Foucault's lecture explains how his notion of critique is similar to Kant's understanding of Aufklärung (Foucault 2007a, pp. 47-58), as well as how his "historical-philosophical" critique may be conducted (Foucault 2007a, pp. 58-67). It would be instructive to determine how exactly this critique is conducted, as well as examine the connection between Foucault and Kant, which would be the analogical definition of critique, but I do not have space to do that here. What I have said about critique, though, is sufficient to explain why it is a genealogy. Critique is genealogy precisely because it determines singularities and contingencies. Here is Foucault: "what is proposed instead is a genealogy, that is, something that attempts to restore the conditions for the appearance of a singularity born out of multiple determining elements of which it is ... the effect" (Foucault 2007a, p. 64; emphasis in the original). In other words, critique as genealogy determines those singularities and contingencies that constitute who or what we are.

There are things and/or events that make truths about ourselves or impose truths on us (e.g., sexuality) and, according to Foucault, these are the same sorts of things that one refuses to believe to be true. Therefore, she rejects whatever she has been made or forced to accept, especially those "truths" about herself. In "What is Enlightenment?", Foucault elaborates what he means by critique, describing it as both the historical analysis of the limits imposed upon us, and an experiment as to the possibility of going beyond them (Foucault 2007b, p. 118). This means that, in doing genealogical critique, one needs to undertake, first, a historical inquiry into those things or events that make her what she is at present, and then determine other possible subjectivities that she can constitute for herself. Otherwise than government, Foucauldian genealogy is an immanent critique of the present. We will see that this is exactly what Drahos accomplishes in critiquing IP. By identifying proprietarianism

5 For example, in The History of Sexuality, vol. 1, Foucault writes: "By power, I do not mean 'Power' as a group of institutions and mechanisms that ensure the subservience of the citizens of a given state. By power, I do not mean, either, a mode of subjugation which, in contrast to violence, has the form of rule. Finally, I do not have in mind a general system of domination exerted by one group over another" (Foucault 2008, p. 92).

6 Foucault writes: "I would have the arrogance to think that this definition ... is not very different from the one Kant provided: not to define critique, but precisely to define ... the Aufklärung" (Foucault 2007a, p. 47). On the following page, he writes: "What Kant was describing as the Aufklärung is very much what I was trying before to describe as critique, this critical attitude which appears as a specific attitude in the Western world starting with what was historically, I believe, the great process of society's governmentalization" (Foucault 2007a, p. 48). 
as the dominant norm in IP and replacing it with instrumentalism, Drahos undertakes Foucauldian genealogy to a certain but significant extent.

\section{Proprietarianism: The Norm in IP}

Before discussing how for Drahos proprietarianism becomes the dominant norm in IP, let me first contextualize his work. His book, A Philosophy of Intellectual Property, was published in 1996 shortly after the signing of the Agreement on Trade-Related Aspects of Intellectual Property Rights, commonly known as TRIPS. Signed on 15 April 1994 by one hundred and eleven countries at the GATT $^{7}$, TRIPS is an international agreement that regulates and promulgates minimum standards of various forms of intellectual property such as patents, trademarks, and copyright for member-nations of the WTO. Drahos explains that TRIPS was initiated by developed countries, particularly the US, to economically coerce developing countries to implement intellectual property laws. He writes: "By helping its multinational clientele to achieve dominium over the abstract objects of intellectual property the US goes a long way towards maintaining its imperium. TRIPS at one level is very much a story about the continuation of US hegemony" (Drahos 1995, p. 16; emphases in the original). ${ }^{8}$ Once a country joins TRIPS, any member nation is able to make a complaint to the WTO if that country is not complying with the requirements of TRIPS. ${ }^{9}$ By linking membership of WTO with adoption of TRIPs, the more powerful developed nations effectively coerced the developing nations to recognize intellectual property rights, most of which were generated and owned by companies originating in the developed countries. Particular examples include the protection given to pharmaceutical composition patents and computer software generally.

Another attempt to further the globalization and "proprietarianization" of IP identified by Drahos in his various works can be seen in the ambitious Trans Pacific Partnership (TPP). The TPP had its origins in a trade agreement in 2005 between four countries in the Pacific region: Brunei Singapore, New Zealand, and Chile, known as the Trans-Pacific Strategic Economic Partnership Agreement. From 2008, various other countries indicated a desire to join that agreement. The end result was the TPP between 12 nations occupying the Pacific Rim including the US, Japan, Canada, Singapore, and Australia, and covering more than $40 \%$ of the world's population. Importantly, from a geo-political perspective, China was not a participant of the TPP. The TPP does contain provisions allowing for further countries to join, and a number of other countries had expressed interest in becoming part of it.

The TPP was signed by all 12 countries on 4 February 2016, and was hoped to be ratified by all of them by 4 February 2018, following which, it would come into effect. Rather ironically, in 2017, the Trump administration of the United States withdrew from the TPP, citing the potential damage to local US manufacturing industries associated with lowering of tariff barriers, among other things. The remaining 11 nations are continuing efforts to proceed with the TPP (now renamed Comprehensive and Progressive Agreement for Trans-Pacific Partnership), but with the relevant IP aspects suspended, pending the hoped-for re-engagement of the United States at a later time. Many of these controversial IP provisions were insisted upon by the United States. With its departure from the TPP, the other countries have decided to suspend the IP provisions for now, but have continued with a partial implementation of the TPP, having reached a revised agreement in November 2017.

Although no longer the powerhouse it would have been, due to the US' departure, the TPP process, like TRIPS, aptly demonstrates Drahos' consistent thesis that IP has become a commodity with the IP-rich developed nations exercising their economic power to encourage developing nations

\footnotetext{
GATT stands for General Agreement on Tariffs and Trade.

8 In another work, Drahos and Braithwaite write: "The case of intellectual property shows the US state and international business mobilising the mechanism of coercion to get developing countries to sign TRIPs" (Drahos and Braithwaite 2001, p. 124).

9 In their book, Drahos and Braithwaite explain that the US takes advantage of TRIPS: "The minute that TRIPS came into force the US began to use the WTO dispute resolution mechanism to obtain compliance with its provisions. It remains to date the biggest litigator under TRIPS"' (Drahos and Braithwaite 2002, p. 113).
} 
to enshrine and perpetuate the proprietarian approach to IP in their local laws. In this sense, it is important to undertake a genealogical analysis of IP for two reasons: first, in order to determine the dominant norm, the identification of which would make it possible to develop forms of resistance and alternatives; and, second, in order to be cognizant of the way power morphs and continues to dominate certain aspects of our lives. In light of this, we now describe the characteristic features of proprietarianism which, according to Drahos, have come to dominate IP.

In contrast to the narrower, natural rights-based notion of proprietarianism advocated by Jeremy Bentham and John Locke, Drahos understands proprietarianism in a broader sense, defining it as a creed which asserts "that the possessor should take all, that ownership privileges should trump community interests and that the world and its contents are open to ownership" (Drahos 2016, p. 235). He further explains that this proprietarian creed consists of three core beliefs: the moral priority of property rights over other rights and interests, the first connection thesis, and the existence of a negative commons (Drahos 2016, p. 235). To elaborate, because it deems property as foundational, proprietarianism according to Drahos prioritizes property rights or interests over others. ${ }^{10}$ The first connection thesis of proprietarianism states that the person who establishes first a connection to an economically valuable object becomes entitled to property or ownership of that object. This can be fulfilled by exercising control over a certain object which, in turn, is guaranteed by first possession rules. The proprietarian belief in the existence of a negative commons means that things are not automatically owned, but are open to ownership by any individual. Taken together, all three beliefs are for Drahos constitutive of proprietarianism. Having explained his own general conception of proprietarianism, Drahos then clarifies how it has infiltrated IP. He shows this not through an extensive empirical investigation, but through a discussion of what he calls "proprietarianism in action," drawing examples from trademark, copyright, and patent laws (Drahos 2016, pp. 236-47). Although it is doubtful that proprietarianism could be characterized completely by these sample practices, we grant that they not only constitute the characteristic features of proprietarianism, but also demonstrate Drahos' contention that proprietarianism has dominated IP law and practice.

In present-day trademark practice, according to Drahos, there is a tendency to prioritize trademark proprietors more than consumers. Because of the growing need for modernization and commercialization, addressing the "needs of the market," trademarks, he says, "become tradeable entities in their own right that serve the interests of their owners" (Drahos 2016, p. 238). Instead of serving consumer and public interests, which used to be the case, trademark proprietors are served first. This significant change in trademark practice, according to Drahos, is brought about by the expansion of the meaning of sign (which now includes colors, movements, shapes, scents, and sounds), the main purpose of which is to protect not the consumers' interests, but those of the traders. It makes sense that a trademark is a badge of origin, indicating the source of the product and enabling the consumer to make assumptions about quality, characteristics, and reputation, perhaps across a range of products to which the trademark is applied. Nonetheless, these attributes are problematic for him, given his assertion that consumer and public interests are increasingly set aside in the modern approach to trademarks.

In its original conception, to be granted a trademark was to be granted a statutory privilege, which privilege was to be exercised within the purpose and intent of trademark law. However, Drahos argues, over time, a trademark has evolved (better yet, devolved) as just another species of commercial property, no different from any other type of property. The trademarks have abandoned their statutory privilege, and joined the indistinguishable host of property rights. As examples of this abandonment, Drahos cites the relatively recent commercial phenomena of trademark licensing and assignment. In these situations, something which was originally conceived as original statutory privilege acquires

10 Drahos explains: “[Proprietarianism] is a creed and an attitude which inclines its holders towards a property fundamentalism. The consequence within normative theory is that property interests are continuously given a moral primacy" (Drahos 2016, p. 234). 
the ability to be alienated to someone else unconnected with the original source or reputation, through licensing or outright sale. He essentially says that when someone is allowed to license or sell the trademark, the primary purpose and function of the trademark as a badge of origin is lost, because the person now using or owning the trademark is not the original source of the trademark. He is correct because, as the franchising model shows, the franchisor or the original owner of the trademark (origin and reputation) grants multiple unrelated parties the right to use the trademark in exchange for a substantial fee. Given the prevalence of licensing and assignment of trademarks, there certainly appears to be some validity to Drahos' argument that the original consumer-oriented purpose of indicating true source or origin has been lost. However, the vast majority of trademarks continue to be used and applied by the original "privileged" holder, and thus, one may say that while there has been a dilution in the original purpose of a trademark, as explained by Drahos, the original purpose of indicating original source continues for many trademarks today.

Turning to copyright, Drahos gives the example of the "sweat of the brow" doctrine to demonstrate how copyright proprietarianism is at work. Illustrated by the United States case of Jeweler's Circular $P u b$. Co. vs. Keystone Pub. Co., the sweat of the brow doctrine simply states that if one puts enough effort into creating something, even something which merely involves the laborious collection of data or facts, it may be protectable by copyright in the US at least. This proprietarian approach to copyright is problematic for Drahos, because it favors privatization of reports of facts, with little or no creative element. He writes: "Copyright proprietarianism in the form of the 'sweat of the brow' doctrine potentially transfers these public domain reports into private hands" (Drahos 2016, p. 242). Consequently, these supposedly "public" domain reports, which are now protected by copyright, enable the "owner" to commercialize this new private property through licensing it to others and extracting payment. As in the case of trademark discussed above, this proprietarian approach "privileges" copyright proprietors, because it enables them to protect something which otherwise would not have been protectable, and for which they can charge a fee. Subsequent cases, in the US and elsewhere, have denied or cast doubt on the validity of the sweat of the brow doctrine on the basis that the relevant material does not meet the copyright requirements of originality and creativity. However, as Drahos points out, the march of proprietarianism continues with the creation of a sui generis database protection right (in place of copyright protection) in some jurisdictions, which explicitly protects such public domain reports and other data compilations involving significant effort. In many ways, this is an even worse outcome from Drahos' perspective because a new proprietary right is created from nothing, as opposed to being created out of the modification of the privilege doctrine on which intellectual property was originally based, nullifying any possibility of arguing for a return to the original roots of the property right (i.e., privilege).

Finally, Drahos explores the field of patents, and explains that, traditionally, discoveries themselves were not patentable, only inventions with an industrial application (Drahos 2016, p. 244). Whereas discovery consists of revealing or unveiling something already existing in the world, invention arises when something new is created which has a useful effect for industry. The observance of the distinction between discovery and invention, according to Drahos, helped shape the traditional goal of the patent system, which was meant to improve skills within current industries and/or create new industries or technical fields. However, with the advent of proprietarianism, the distinction between discovery and invention is blurred, if not abolished. The proprietarian approach to patent, he says, argues that discovery should be "the subject of a patent right," because the process of discovering "can be [as] costly, labour-intensive and economically valuable" as an invention (Drahos 2016, pp. 245-46). In this cost-based justification, one sees a similar approach to that taken in relation to granting copyright protection for laborious (if rather uncreative) data compilations under the sweat of the brow doctrine. Discovery, then, like invention, becomes patentable from the proprietarian perspective. With the proprietarian influence, biological materials, such as genes, newly discovered plant and animal species, including those that are bred by growers or breeders, may now be granted patent rights or plant breeders rights in some jurisdictions, although, since Drahos wrote, this window is gradually closing, 
due to various court decisions and legislative changes around the world narrowing the field of patentable subject matter. According to Drahos, if proprietarianism continued to dominate the patent system, it would not be long until every piece of abstract information belonging to the public domain would be held privately by a select few. To Drahos, this would be problematic, because it would betray the true function of the patent system, which is meant to protect not useful ideas (e.g., a discovery), but a method of manufacture (e.g., patentable invention). Something that was potentially publicly available for use by anybody now becomes captured under the individual control of the patent owner who can then prevent others from using it without permission and payment.

It is now easy to understand why Drahos is critical of the proprietarian approach to intellectual property. He rejects proprietarianism because it prioritizes the rights of proprietors of intellectual property over the rights of the public, as well as espouses the privatization of such abstract objects as intellectual property, which he says poses a threat to "the core value of negative liberty" (Drahos 2016, p. 248). In describing intellectual property rights, he complements the classical formulation of negative rights that merely includes rights to "life, liberty and property" (Drahos 2016, p. 248). Intellectual property rights to him are not just negative rights, but are also "liberty-inhibiting privileges" (Drahos 2016, p. 250). This means that they allow the person who has the privilege to exercise it to inhibit the freedom of others to do things protected by the privilege. Unlike tangible assets, such as land or equipment, IP rights do not impact in a physical way, being incorporeal, but they impact any activity of any person that is within the scope of the abstract object (i.e., the subject matter of the particular intellectual property). As such, the inhibition of liberty can potentially apply on a global basis, rather than a territorial one, as would be the case for physical property, such as land or an item of equipment. It appears though that the distinction between the classical conception of property as negative rights and Drahos' broader notion of intellectual property rights as liberty-inhibiting privileges is marginal. For, it may be true that negative rights are themselves rights, whereas intellectual property rights may be viewed as "privileges" (at least in the original and Drahos' conception of it) and have more global importance than, say, ownership of a piece of land; nevertheless, both share the same "negative" quality of freedom restriction that enables its owner to interfere with the activities of others with respect to the (intellectual) property in question. Arguably, the only difference between the two is that the territorial effect is limited physically in the case of land, while the territorial effect for intellectual property is limited to the scope of the relevant IP. Thus, both intellectual property and other sources of rights have a territorial limitation, even if the nature of that territorial limitation differs, given the differing nature of the relevant property (abstract or otherwise).

In lieu of the proprietarian approach to intellectual property, Drahos posits instrumentalism, which has a twofold characteristic: (a) humanistic; and (b) naturalistic. Instrumentalism is humanistic, because it seeks to improve the human condition and experience by maximizing not just physical, but also human capital. It is naturalistic, because it conceives of intellectual property rights as natural rights or privileges which must be exercised responsibly, and seeks to eliminate the idea of property as a mere economic right or commodity free of any responsibility to consider others. Drahos applies the term instrumentalism because he argues that IP should be considered as an instrument to improve the human condition, rather than being an end in itself or a source of unqualified rights for the holder. Thus, IP is to return to its original roots as a privilege with which comes responsibilities as well as rights, and the responsibilities are to exercise the privilege in a way which benefits not only the holder, but also the public. Considering intellectual property rights as privileges to Drahos entails more responsibility for their owners for, following Hohfeld, there is a correlativity between duties and privileges (Drahos 2016, pp. 173, 248). Having described how for Drahos proprietarianism has become dominant in characterizing the nature and operation of IP, I am now going to explain how his approach to genealogy falls short of Foucault's methodology. 


\section{Drahos' Departure from Foucault: A Quasi-Genealogy}

As mentioned, Drahos briefly examines Foucault's analysis of power, consisting merely of two pages (Drahos 2016, pp. 175-77). It would be counterproductive to overemphasize the importance of these two pages, since it is not Drahos' intention to expound Foucault's notion of power, much less give a detailed account of what power is in general. Though not exhaustive, Drahos' treatment is not an unfaithful reading of Foucault's analysis. On the contrary, Drahos gives an accurate interpretation of Foucault's notion of power. His two-page analysis may seem somewhat insignificant, but it still sheds light on and plays an important part in his genealogy of IP.

Drahos' analysis of Foucault's notion of power appears to be a small digression from his discussion of "Power of Abstract Objects" in chapter 7, which explains the unique relationship between intellectual property and power in general. Written under the section "Property and Private Sovereignty," it seems to be an elaborate addendum to his well-reasoned position in support of Morris Cohen's argument for private property as "a form of sovereignty over others" (Drahos 2016, p. 172) using Wesley Hohfeld's thesis of correlativity between right and duty (Drahos 2016, p. 173). I will not go into the details of Drahos' presentation of Cohen's argument, but will simply suggest that his analysis of Foucault can be better understood when placed in the context of this discussion.

Drahos correctly points out that Foucault does not endorse the traditional juridical conception of power. This is consistent with the commonly held understanding, Cutrofello's in particular, of Foucault's project as "a sustained attempt to formulate a nonjuridical model for Kantian critique" (Cutrofello 1994, p. x). In contrast to the juridical (i.e., negative) conception of power, says Drahos, Foucault conceives of it "in terms of flow and network concepts" (Drahos 2016, p. 175). He identifies quite accurately that Foucault's notion of power is not one which links power to sovereignty or a "top-down" model, but rather is that which views power as "exercised" in and through a number of means (Drahos 2016, p. 175). ${ }^{11}$ Foucault's conception of power may then be said to be "positive", since it is neither restrictive nor obstructive, unlike its traditional juridical counterpart. The problem with the nonjuridical conception of power, according to Drahos, is that it fails to give a satisfactory answer to the question of how individuals harness power: "The analytical shift to conceiving of power as a polycentric phenomenon has still to confront and explain how individuals harness power" (Drahos 2016, p. 176). The "best" (that is, for Drahos, inadequate) explanation that this positive, fluid, and net-like conception of power could give is that there are mechanisms that enable individuals precisely to harness power. ${ }^{12}$

It is not clear in his text, but Drahos seems to suggest that there has to be more to individuals harnessing power than simply being enabled by empowering mechanisms. This is what he writes: "[A]n important question remains to be answered: how do agents within the relevant network harness power flows? Clearly, individual agents have to harness power in order to exercise it" (Drahos 2016, p. 175). In other words, for Drahos, before individuals can even exercise power, they must possess it in the first place. His observation is correct, and his criticism of Foucault justified. It may sound clichéd but, to paraphrase Theodore Roosevelt, one can only do what one has. ${ }^{13}$ However, if Drahos is seeking to account for that "more" in individuals' harnessing of power, in my understanding he fails, because he relies solely on the mechanism of intellectual property for his

11 For an interesting debate on Foucault's notion of power, see Charles Taylor and Paul Patton's essays (Taylor 2014a, 2014b; Patton 2014a, 2014b) that have been re-published in David Owen's edited work, Michel Foucault (Owen 2014). Patton (2014a) rectifies Taylor (2014a) misconception of Foucault's notion of power first by pointing out that power for Foucault "creates subjects" and, second, by distinguishing "power to" from "power over." The ability to create subjects and the idea of "power to" to Patton determine the positive sense by which Foucault understands "power." Drahos captures this "positive" sense of Foucault's notion of power in his brief commentary on Foucault.

12 Drahos writes: "[T]he answer to this question has to be given in terms of mechanisms that allow the individual agent (A) to concentrate to some degree the flow of power so that A can affect B in a manner contrary to B's interests" (Drahos 2016, p. 175).

13 Quoting a certain Squire Bill Widener, Theodore Roosevelt writes: "Do what you can, with what you've got, where you are" (Roosevelt 1916, p. 350). 
explanation. As such, he puts himself in an awkward position because he subjects himself to his own criticism of Foucault. Being focused on one sovereignty mechanism (i.e., intellectual property), his explanation for how individuals harness power appears to be less convincing than Foucault's more general account of power mechanisms.

Nevertheless, having identified an inadequacy in Foucault's nonjuridical analysis of power, in the later sections, Drahos offers his own account of the way individuals harness power. ${ }^{14}$ Surprisingly, at this juncture of his argument, he claims that his "analysis converges nicely with Foucault's" (Drahos 2016, p. 175). Indeed, his and Foucault's analyses converge for, whereas Foucault considers law to be "an instrument of power," Drahos identifies property as "a law-dependent mechanism of power" (Drahos 2016, p. 176). This means that law and property are, for Foucault and Drahos, respectively, two of the many forms that power or sovereignty assumes and through which it continues to dominate our lives. Their convergence becomes even more apparent when, having adopted "Foucault's emphasis on mechanisms of power" (Drahos 2016, p. 176), Drahos claims that property is a "sovereignty mechanism," which to him is one way by which individuals acquire power. ${ }^{15}$ From this, it would not be difficult for him to draw the conclusion that "intellectual property not only is a sovereignty mechanism but it [also] has a sovereignty effect in social systems" (Drahos 2016, p. 185).

As soon as an alliance between Drahos and Foucault is forged, however, it is broken because, although he subscribes to Foucault's account of the "mechanisms of power," Drahos avoids the most important goal of Foucault's genealogy of power; namely, the displacement of sovereignty. Drahos is well aware that the purpose of Foucault's account is not only to show that the juridical conception of sovereignty is flawed but, more importantly, to displace it. However, he explicitly chooses not to follow Foucault mainly because, as I have said, he refuses to sever ties with sovereignty: "Here our analysis parts ways with Foucault's, for he is seeking to replace the juridical-political theory of sovereignty ... The approach being advocated here adopts Foucault's emphasis on mechanism of power, but retains the link to sovereignty" (Drahos 2016, p. 176; emphases mine). Instead of metaphorically "cutting off the head of the king" as Foucault attempts to do (Foucault 2008, p. 89), Drahos wants to keep the Leviathan alive which, he says, now morphs into intellectual property that has a sovereign effect. ${ }^{16}$

What this shows is that, despite acknowledging the convergence between his and Foucault's analyses, and in spite of adopting Foucault's strategy, Drahos is ultimately at odds with Foucault's conception of power, and the sources of power. Instead of following Foucault, he deliberately espouses the juridical conception of power, which is the very conception Foucault put into question. In continuing to subscribe to the traditional juridical conception of power, Drahos places himself in a precarious position. Despite this, one can still appreciate the value of Drahos' genealogy of IP, which consists precisely of detecting the transformation of sovereign power itself. Ultimately, however, one cannot say that Drahos is faithful to the spirit of Foucauldian genealogy. For, to do so would never result in the preservation of sovereignty in any form. Of course, Drahos explicitly noted that he was departing from Foucault on this point.

A number of Foucault's followers support our claim, contending contra Drahos that the end result of genealogy should be the decentering, if not the total elimination, of the juridical conception of power. Drawing from Foucault's conception of power "without the king" (Foucault 2008, p. 91), they would say that genealogy has no other goal except to forego any analysis of power that is based

14 From page 192 onwards, Drahos (Drahos 2016) gives the example of pharmaceutical companies. He explains that they have vaster "threat power" than land owners precisely because of their ownership of patents over certain drugs, which is much more extensive than the ownership of a piece of land. For Drahos, the mere ownership of abstract objects such as copyright, trademark or patent therefore enables their owners to harness power.

15 Here is Drahos: "Our purpose here is not to give a general description of the mechanisms that can be utilised to harness power. Rather the purpose is to show that property is one such mechanism, what we might call a sovereignty mechanism" (Drahos 2016, p. 175).

16 Drahos writes: "Thus we should not follow Foucault when he suggests that we should 'eschew the model of Leviathan in the study of power' (Foucault 1980, p. 102). Instead we need to recognise that, through mechanisms of power, Leviathan changes its shape and produces progeny, which ultimately come to threaten its supremacy" (Drahos 2016, p. 177). 
on law and/or sovereignty, or to topple down any power that has held us captive and has never been questioned up until now. David Owen, for example, claims that genealogy is a form of critique that enables "us to free ourselves from a condition of aspectival captivity" (Owen 2014, p. 58). The idea of genealogy emancipating us from captivity is also captured by Martin Saar when he argues that "the critical aim of genealogy ... [consists] in installing a devaluating, delegitimizing vocabulary within genetic descriptions of existing norms and values" (Saar 2014, p. 77). The language of "freedom from," devaluation or de-legitimization used by these Foucauldian scholars to describe genealogy is very consistent with Foucault's immanent critique of the present explained above, which seeks to determine the dominant norm, analyze it historically, and investigate ways by which to go beyond it.

For his part, Drahos could respond by saying, what he is doing in IP is consistent with Foucauldian genealogy. He may not have the same goal of discarding sovereignty as Foucault, but he nonetheless still undertakes an important aspect of Foucauldian genealogy. As we have seen, he starts off by analyzing the status of IP and, having determined that it has long been dominated by proprietarianism, he seeks to emancipate IP from it. Similar to what Foucault does to the juridical notion of power that he seeks to displace, Drahos not only shows how proprietarianism has remained unchallenged in IP but, more importantly, displaces it with his notion of instrumentalism. From this, one can deduce that for Drahos, what is crucial for any genealogical work is not so much the displacement of sovereignty, as analyzing its dominance and effecting a transformation of its goals and purposes. There is therefore a parallelism between Foucauldian genealogy and Drahos' genealogy of IP. Drahos not only emulates Foucault by determining intellectual property as a sovereign mechanism but also undertakes Foucauldian genealogy by applying its core principles. A question still remains: would it really be possible to emancipate IP from proprietarianism if one still clings on to sovereign power?

The short answer is, no. It is impossible to truly emancipate IP if one continues to adhere to a sovereign, juridical notion of power as Drahos does. For, obviously, one remains captive to a dominant form of power. In doing genealogy, while laudable, it is nonetheless insufficient to "simply" determine a dominant norm, analyze it historically, and propose a new norm that would replace it. Drahos has simply replaced one master with another, very similar, master (or perhaps masters, in the form of "sovereignty mechanisms"). As Saar argues, it is not by creating new or neutral norms that constitutes genealogy (Saar 2014, p. 67). As we have seen, this is exactly what Drahos does; in lieu of proprietarianism, he posits the instrumental view for IP. With this, his genealogy of IP falls short of Foucault's methodology, with the result that Drahos' approach, as I have argued, may be considered a quasi-genealogy. For, although it identifies and analyzes the dominant proprietarian norm historically, it maintains its link with sovereign power. In order for it to be a full-fledged genealogy, it must sever ties from sovereignty. Cutting off the head of the king is the only way by which one can emancipate IP, but perhaps this would demand too much from Drahos or any genealogist of IP for that matter. One can sympathize with Drahos when he argues that IP, as a creation of law, is such that it can never be independent from law and, ultimately, the sovereign. The best that a genealogy of it can do is to identify how the sovereign morphs, and determine the form it assumes.

Cutting off the head of the king in the context of IP, therefore, at its most extreme could mean the dissolution or abandonment of the whole concept of IP itself. A less extreme version might involve the replacement of existing laws with new laws or norms, which vary widely from region to region or country to country, according to the needs and attitudes of the citizens of that place, rather than a uniform system which favors the few at the expense of the many. Drahos and others might argue that without law and sovereignty, IP loses substance. That is, an underlying Leviathan is essential to the creation and maintenance of a workable scheme of IP. On this view, the necessity of maintaining sovereignty in the specific, concrete context of IP demonstrates that Foucauldian genealogy may be too ambitious a project or that the standards it sets may be too high to accomplish. It is one thing to prescribe a theoretical model, and another to implement it in the real world with its existing power relations and, in the specific case of IP, trade and regulatory globalization. Foucauldian scholars may defend Foucault, saying it was never Foucault's intention to be prescriptive, but to be 
descriptive instead, recognizing that each application must be considered in its particular context. Nevertheless, when brought down to the rough grounds of IP law and practice, Foucault's exhortation to cut off the head of the king falls on deaf ears in view of the overwhelming political, trade, and intellectual dominance of the developed nations now enshrined in the various global and regional treaties. Foucault would not ignore these realities, as he did not in the various genealogical studies he undertook. Instead, he would exhort us to resist these structures as best we can, with a view to improving outcomes, despite even partial decapitation of the errant sovereign not being possible.

\section{Conclusions}

Foucault's genealogy is an immanent critique of the present; immanent, because it never leaves the domain of history, but ascertains and surpasses any limit imposed upon us by means of historical analysis and experimentation, thereby undertaking critique from within the present itself. Drahos' genealogy of IP may be correctly described as Foucauldian in that it seeks to emancipate IP from the dominant proprietarian view, determining thus a norm-limit in IP, as well as postulating a way of moving beyond it through the instrumentalist view of intellectual property. In his work that examines the origins, purpose, and current state of intellectual property, Drahos finds that it was originally grounded in the language of privilege, with attendant duties on the privilege holder. He carefully identifies the transfer of power away from the public and in favor of owners, showing that, over time, intellectual property has devolved into mere proprietarianism, becoming just another category of property. Having identified these power relations, he proposes a recharacterization of IP to seek to reinstate its legacy as privilege-bestowing both power and responsibility. Despite this, his approach explicitly falls short of Foucauldian genealogy, and hence, may only be understood as a quasi-genealogy, by maintaining its link to sovereignty, and seeking to keep the Leviathan alive. Cutting off the head of the king would be the final step to making it a full-fledged genealogy, but perhaps it is impossible for any genealogy of IP to do so as IP will always be based on law, and law is the hand, if not the head, of the king.

Acknowledgments: I would like to thank the Australian Government Research Training Program Scholarship for the support given to me. My heartfelt gratitude goes to my supervisor, Paul Patton, who commented on parts of the paper. Thanks also to Marie Rose Arong for her comments and to the reviewers for their helpful feedback. Finally, I am very grateful to Christopher Bevitt who was my sounding board while writing the paper and from whom I learned a great deal about IP.

Conflicts of Interest: The author declares no conflict of interest.

\section{References}

Allen, Amy. 2014. The Normative and the Transcendental: Comments on Colin Koopman's Genealogy as Critique. Foucault Studies 18: 238-44. [CrossRef]

Cutrofello, Andrew. 1994. Discipline and Critique: Kant, Poststructuralism, and the Problem of Resistance. New York: State University of New York Press.

Drahos, Peter. 2016. A Philosophy of Intellectual Property. Acton: ANU eText. First published 1996; Aldershot: Ashgate/Dartmouth, Available online: https://www.researchgate.net/publication/304514536_

A_Philosophy_of_Intellectual_Property (accessed 11 October 2017).

Drahos, Peter. 1995. Global Property Rights in Information: The story of TRIPS at the GATT. Prometheus 13: 6-19. [CrossRef]

Drahos, Peter, and John Braithwaite. 2001. The Globalisation of Regulation. The Journal of Political Philosophy 9: 103-28. [CrossRef]

Drahos, Peter, and John Braithwaite. 2002. Information Feudalism. London and Sterling: Earthscan.

Foucault, Michel. 1980. Two Lectures. In Power/Knowledge: Selected Interviews and Other Writings 1972-1977. Edited by Colin Gordon. New York: Pantheon Books, pp. 78-108.

Foucault, Michel. 2002. The Archaeology of Knowledge. Translated by A. M. Sheridan Smith. London and New York: Routledge. 
Foucault, Michel. 2007a. What is Critique? In The Politics of Truth. Edited by Sylvère Lotringer. Los Angeles: Semiotext(e), pp. 41-81.

Foucault, Michel. 2007b. What is Enlightenment? In The Politics of Truth. Edited by Sylvère Lotringer. Los Angeles: Semiotext(e), pp. 97-119.

Foucault, Michel. 2008. The History of Sexuality: The Will to Knowledge. Translated by Robert Hurley. Camberwell: Penguin Books, vol. 1.

Sophie Fuggle, Yari Lanci, and Martina Tazzioli, eds. 2015. Foucault and the History of Our Present. Basingstoke and New York: Palgrave Macmillan.

Gordon, Colin. 1986. Question, Ethos, Event: Foucault on Kant and Enlightenment. Economy and Society 15: 71-87. [CrossRef]

Koopman, Colin. 2013. Genealogy as Critique: Foucault and the Problems of Modernity. Bloomington and Indianapolis: Indiana University Press.

Koopman, Colin. 2014. Genealogy, Methodology, \& Normativity beyond Transcendentality: Replies to Amy Allen, Eduardo Mendieta, \& Kevin Olson. Foucault Studies 8: 261-73. [CrossRef]

Mendieta, Eduardo. 2014. On Left Kantianism: From Transcendental Critique to the Critical Ontology of the Present. Foucault Studies 18: 245-52. [CrossRef]

Olson, Kevin. 2014. Genealogy, Cryptonormativity, Interpretation. Foucault Studies 18: 253-60. [CrossRef]

Owen, David. 2014. Criticism and Captivity: On Genealogy and Critical Theory. In Michel Foucault. Edited by David Owen. Farnham and Burlington: Ashgate, pp. 47-61, Originally published as 2002. European Journal of Philosophy 10: 216-30. [CrossRef]

Patton, Paul. 2014a. Taylor and Foucault on Power and Freedom. In Michel Foucault. Edited by David Owen. Farnham and Burlington: Ashgate, pp. 121-37, Originally published as 1989. Political Studies 37: 260-76. [CrossRef]

Patton, Paul. 2014b. Foucault's Subject of Power. In Michel Foucault. Edited by David Owen. Farnham and Burlington: Ashgate, pp. 145-56, Originally published in French as 1992. Sociologie et Sociétés 24/1. The first English version appeared in 1994. Political Theory Newsletter 6: 60-71.

Revel, Judith. 2015. 'What Are We At The Present Time?' Foucault and the Question of the Present. In Foucault and the History of Our Present. Edited by Sophie Fuggle, Yari Lanci and Martina Tazzioli. Basingstoke and New York: Palgrave Macmillan, pp. 13-25.

Roosevelt, Theodore. 1916. An Autobiography. New York: Macmillan.

Saar, Martin. 2014. Genealogy and Subjectivity. In Michel Foucault. Edited by David Owen. Farnham and Burlington: Ashgate, pp. 71-85, Originally published as 2002. European Journal of Philosophy 10: 231-45. [CrossRef]

Tanke, Joseph. 2009. Foucault's Philosophy of Art: A Genealogy of Modernity. London and New York: Continuum.

Taylor, Charles. 2014a. Foucault on Freedom and Truth. In Michel Foucault. Edited by David Owen. Farnham and Burlington: Ashgate, pp. 89-120, Originally published as 1984. Political Theory 12: 152-83. [CrossRef]

Taylor, Charles. 2014b. Taylor and Foucault on Power and Freedom: A Reply. In Michel Foucault. Edited by David Owen. Farnham and Burlington: Ashgate, pp. 139-43, Originally published as 1989. Political Studies 37: 277-81. [CrossRef]

Visker, Rudi. 1995. Michel Foucault: Genealogy as Critique. Translated by Chris Turner. London and New York: Verso.

(C) 2018 by the author. Licensee MDPI, Basel, Switzerland. This article is an open access article distributed under the terms and conditions of the Creative Commons Attribution (CC BY) license (http://creativecommons.org/licenses/by/4.0/). 